\title{
The Impact of Using Task-based Writing on EFL Learners' Writing Performance and Creativity
}

\author{
Hamid Marashi \\ Islamic Azad University at Central Tehran, Iran \\ Email: ahmuya@yahoo.com \\ Lida Dadari \\ Islamic Azad University at Central Tehran, Iran \\ Email: lidadadari@yahoo.com
}

\begin{abstract}
This study investigated the impact of task-based writing on EFL learners' writing performance and creativity. For this purpose, 56 female intermediate Iranian EFL learners were chosen from a total number of 89 through their performance on a sample piloted PET. Based on the result, the students were randomly assigned to one control and one experimental group with 28 participants in each. Prior to the treatment, students took part in a writing test (part of PET) and the Abedi-Schumacher Creativity Test (ACT) as pretests. Both groups underwent the same amount of teaching and the same writing topics during 18 sessions of treatment. The only difference was that the experimental group was engaged in doing task-based writing activities while the control group was not asked to do any kind of tasks. At the end of the treatment, a writing test (another PET) and the ACT were administered to both groups. The results of the statistical analysis demonstrated that learners benefited significantly from task-based writing in terms of both their writing and creativity.
\end{abstract}

Index Terms - writing, creativity, task-based writing

\section{INTRODUCTION}

Writing today has become very important in the daily lives of much of the world's population and speakers of globally dominant languages are surrounded by written materials. Writing is an important and, at the same time, demanding activity, particularly in a foreign language context in which learners are exposed to language just for few hours a week (Kim \& Kim, 2005).

Despite this importance, writing has received less attention in English language teaching; in the words of Richards (1990), "The nature and significance of writing have traditionally been underestimated in language teaching" (p. 106) while writing activities provide learners with the "opportunity to witness their own advancements, reconsider the final draft, and make essential editions throughout the writing process" (Moor as cited in Tilfarlioglu \& Basaran, 2007, p. 141).

\section{Task-Based Writing}

The recent years have seen a growing interest in task-based language teaching (TBLT), and the role of tasks in second or foreign language acquisition. TBLT, a methodology that is widely used in language learning (Ellis, 2003; Willis \& Willis, 2007), is believed to be known as an approach which enjoys the potential to make up for the inadequacies of communicative language teaching (CLT) and can be considered as "a logical development of it" (Richards \& Rodgers, 2001, p. 223). Techniques, principles, and process- or product-based applications of TBLT and their contribution to foreign language learning and acquisition have been among the most debated topics in the field of foreign language teaching since the early 1990s (Klapper, 2003; McDonough, 1995; Szymanski, 2002).

Task-based writing instruction within the larger framework of TBLT makes learners involved in active mutual work on tasks that are reasonable for them and related to their real life experience (Kawachi, 2003; Ryan \& Deci, 2000).

Concerning writing task features, researchers have argued over some characteristics of tasks such as the amount of time available to learners (Chaudron, 1985), whether the task is completed individually or collaboratively (Oxford, 1997), whether the task is reciprocal or nonreciprocal (Ellis, 1991), and concluded that all these factors affect the process of learning how to write.

There exist different types of tasks to foster the writing performance of the learners. Yet despite their diversity, taskbased writing activities "are done with the purpose of producing something, reaching a conclusion, or creating a whole picture of something within a preset framework" (Tilfarlioglu \& Basaran, 2007, p. 135).

Creativity

The field of creativity as it is known today has been developed basically thanks to the outstanding attempts made by Guilford and Torrance (as cited in Sternberg, 2009). In the modern world, creativity is fundamentally important in all 
aspects of life and since creativity is complex in nature, different viewpoints have been put forward to explain the concept emphasizing different aspects of it (Sarsani, 2006).

As stated by Lubart (1999), creativity is generally characterized as the ability to create new and original products which are considered as appropriate for the features and limitations of a given task, where products can refer to a variety of ideas, viewpoints, and innovations. "These products must be original as they should not be just a mere copy of what already exists" (Lubart \& Guignard, 2004, p. 43). Accordingly, humans are all born with a huge potential for creativity and learning in varying degrees and creativity can be nurtured "at all ages and in all fields of human endeavor" (Sarsani, 2005 , p. 47). To this end, developing creativity at all levels in the education system is increasingly recognized as being critical in improving educational attainment and life skills (Agarwal, 1992); second/foreign language teaching of course is one such educational attainment and arguably a life skill. Hence, in the words of Carter (2004), "Discussions of creativity in relation to language teaching and learning have been extensive and continue to be a very major point of application of a wide range of theories of creativity" (p. 213).

Writing tasks also require creative thinking skills as they involve some operations, and a wide range of information is contained in the final product (Kellogg, 1994; Rao \& Prasad, 2009). Since imagination and creative thinking are central concepts of creative writing, students need be encouraged to develop these processes in their writing task (Bernholz, Cappleman, \& Sumner, 1992; Neira, 2008).

In the actual context of classrooms, learners encounter various types of writing tasks while they consider these tasks "as an unwelcome chore bereft of any creative element" (Parameswaram, 2007, p. 172). In all actuality, "Creativity is an inherent aspect of all pedagogical tasks" (Mishan, 2005, p. 83) and it is of utmost importance for task-based classes to have a favorable, and helpful environment which encourage learners to be more creative (Errey \& Schollaert, 2003).

Through the use of tasks, learners are supplied with an environment in which they can practice and learn English, and improve their creative capacity and critical thinking skills (Lee, 2004). Of course, "Developing creativity in writing is not a fanciful extra in learning to write, but is central to creating writers" (Grainger, Goouch, \& Lambirth, 2005, p. 13).

Having said the above and with respect to the fact that research demonstrates that L2 writers frequently come up with texts that are not qualified (Silva, 1993; van den Bergh, Rijlaarsdam, \& Sanders, 2005), the researchers in this study sought to investigate the impact of using task-based writing on EFL learners' writing performance and their creativity. Accordingly, the following null hypotheses were formulated:

$H_{01}$ : Using task-based writing has no significant impact on EFL learners' writing performance.

$H_{02}$ : Using task-based writing has no significant impact on EFL learners' creativity.

\section{METHOD}

\section{A. Participants}

The participants of this study were 56 female intermediate EFL learners with the age range of 13-18 in one of Tehran's private language schools. They were selected from 89 students based on their performance on a piloted sample PET (those whose scores fell between one standard deviation above and below the mean were selected). Then, they were randomly divided into one control and one experimental group with 28 students in the two groups each. To make sure that the participants in the two groups bore no significant difference in terms of their writing prior to the treatment, the researchers administered a writing test to both groups.

In addition, as this study entailed scoring of writing papers, two raters who both enjoyed a significant inter-rater reliability ( $\mathrm{r}=0.77$ at the 0.01 level of significance) were used for the scoring.

\section{B. Instrumentations}

\section{General Language Proficiency Test (PET)}

Prior to the beginning of the course, a piloted sample PET with the reliability of 0.87 was administered to homogenize the participants of this study in terms of their general proficiency and writing.

\section{Creativity Test Used As a Pretest and a Posttest}

After selecting the participants of the study, a creativity test was given to them to measure their creativity before receiving the treatment. This test is designed by O'Neil, Abedi, and Spielberger and called the Abedi-Schumacher Creativity Test or the ACT (as cited in Cropley, 2001). The ACT consists of 60 multiple-choice items used for establishing the scores of the four traits underlying creative thinking and is thus divided into the four subscales of fluency (22 items), flexibility (11 items), originality (16 items), and elaboration (11 items). Each item has three options ranging from least to most creative responses with a range of scores between 0-2. Therefore, the ultimate score is estimated in a range between 0-120, and participants are supposed to answer the items in 60 minutes.

The estimated reliability of each of the subscales of the ACT has been reported to be between 0.61 to 0.75 which demonstrates that the test is also reliable (Auzmendi, Villa, \& Abedi, 1996).

\section{Writing Posttest}

The other posttest used in this study was another version of the PET test writing paper part 2 and 3. The PET General Mark Schemes for Writing provided by Cambridge was used in this study for the purpose of rating the participants' performance on both writing tests. 


\section{Materials}

\section{Main Course Book for Both Groups}

The third and fourth units of the course book Top Notch 3A by Saslow and Ascher (2006) were used as the main instruction material in both groups. The purpose of this book is to integrate the four language skills along with vocabulary, grammar, and pronunciation. It is aimed to provide learners with authentic and practical language and enable them to interact confidently and successfully.

\section{Touchstone 3}

The researchers also used Touchstone 3 by McCarthy, McCarten, and Sandiford (2006). This course book is designed for intermediate purposes and consists of 12 units each containing four lessons (A, B, C, and D). The writing tasks of this book are provided in lesson $\mathrm{D}$ of each unit with their focus mostly directed toward paragraph writing which made them appropriate for the purpose of this study.

\section{Procedure}

Following the participant selection process (described above) and with the commencement of the treatment, the learners in both groups were exposed to the same course book for 18 sessions each lasting 90 minutes. In the control group, the teacher (one of the researchers) introduced six writing topics which were exactly the same as the topics used in the experimental group. Each writing session started with 15-20 minutes of brainstorming or guided questions and answers in both groups. The only difference was that the learners in the control group were not asked to do any kind of tasks. The six writing topics used in both groups were under these headings:

- The Chance of Living the Last Year Over Again

- A Review of an Interesting Movie, Book, etc.

- A Family Memory from Your Childhood

- Your Best Friend

- Possible Ways of Recycling Unwanted Objects

- An Exciting Experience You've Had.

In the control group, each topic was dealt with in three phases: warm-up, main activity, and follow-up. The first two phases taking 60 minutes of a session began with presenting the topic by the teacher, followed by brainstorming or guided questions and answers. Afterwards, students were asked to write whatever came to their mind as their first draft. After finishing their writings, they were asked to revise and redraft them.

The last phase, follow-up, was postponed to the next session and lasted for 30 minutes. Students were asked to bring their writings to the class. Then, they randomly came to the front of the class and read their writings. This phase culminated in a class discussion over the writings read in that specific session and the ideas proposed by the writers.

In the experimental group, however, a task-based framework was adopted with each task having three phases: pretask, during task, and post-task. The time allocated to each phase was exactly the same as the control group, meaning that pre-task and during task phases occurred in one session for 60 minutes and the post-task was postponed to the next session and took 30 minutes.

A brief summary of each topic used for the treatment in the experimental group is presented hereunder. Once the first topic was introduced, a guided Q\&A followed. Then, the students were divided into pairs to talk about their own wishes. Subsequently, they were provided with a reading model and were asked to start their writings and complete them in class. As a post-task, students were divided into pairs and the writings were exchanged among them. Each student in a pair read her partner's work to provide her with necessary feedback and make a comparison between her own and her partner's ideas. Then, each pair discussed over the differences and the reason of the given feedbacks.

For the second topic, some picture prompts were used to initiate a guided Q\&A followed by a reading prompt provided as a model. Then in pairs, the learners talked about their experiences to come up with ideas needed for their writing. Subsequently, each student wrote a paragraph on her own experience in class. As a post-task, learners were placed in pairs and their writings were swapped between them. Each student in a pair had to read her partner's writing and provide her with feedback and underline anything that did not make sense to her. Then, the writings were swapped back to discuss the given feedbacks and the ideas they had on each other's experience.

The third topic was introduced with a focus on three picture prompts of some unwanted clothes, games, toys, and magazines. The presentation of the prompts continued by brainstorming and listening to an audio CD in which three people talk about the objects in the pictures and what they can do with them. Subsequently, the students were provided with a model Q\&A to read and were next divided into pairs and started to write a question on a clutter problem. After writing the questions, they swapped their writings between the partners and then they were assigned to write a paragraph in response to their partners' question as homework. As a post-task, the pairs got back together and reswapped their writings. Each student read the answer to her problem and, ultimately, they went through a discussion to express their ideas on each others' solutions and anything that could be added or altered to make them more acceptable.

The fourth topic was presented and followed by a guided Q\&A. The students were thence divided into pairs to talk about their friends and a reading model was given to each pair. After reading the model, they were asked to write a paragraph on the given topic in class. As a post-task, the learners were placed in pairs and exchanged their writings with 
a partner to read and provide suggestions that they believed would make the writing more appealing. Afterwards, the suggestions were discussed between the partners in each pair.

The fifth and penultimate topic prompted the students to focus on three picture prompts and express their ideas about them. After brainstorming, an audio CD was played and the students were supposed to listen to come up with a general understanding about it. Next, they discussed their own family memories in pairs, and received a model to help them with the writing. They were supposed to initiate their writing in class and complete it as homework. As a post-task, students were divided into pairs and swapped their writings to read and underline anything that needed to be made clearer or omitted, and discussed whether they agreed with the changes or not.

For the last topic, first, a picture prompt was used accompanied by a guided Q\&A. An audio CD, in which someone read a review of a circus was played and the students completed a checklist given to them in advance. Afterwards, they were divided into pairs to talk about a show, movie, or book they had enjoyed. At the next stage, they were provided with a reading model to help them in writing their paragraphs. The writings were initiated in class and completed at home. As a post-task, the students were divided into groups and swapped their writings to read each others' works and provide their group with a summary of the writing they had read.

Note has to be taken that the whole procedure for the post-task phase was done under the supervision of the teacher. She monitored the pairs or groups and provided them with necessary comments while they were discussing the given feedbacks or ideas. As mentioned earlier, the nature of the peer comments was of two types: one with a focus on the ideas developed in each writing, which was explained in detail for each task, and the other, under the heading of feedback, which was used in some tasks with a focus directed toward punctuation, grammar, and spelling based on the points they had learned up to then. Since the purpose of this study was to develop the writing capacity and creativity of the learners, the focus of most of the tasks was on the first type of comments.

It is also worth noting that at the end of each writing in both groups, the teacher randomly called the name of some of the students and collected their writings to provide them with her comments while her focus was mostly directed toward the development of the ideas, cohesion, and compositional organization. For the next session, she gave a score to each paper and gave them back to the students.

After the instruction period for both groups, the two posttests of writing and creativity were administered.

\section{RESULTS}

All the data analysis procedures and results are presented and discussed in the chronological order of participant selection, pretest and posttest administration, and testing the hypotheses.

\section{Participant Selection}

Following the piloting of a sample PET which showed an acceptable reliability of 0.87 , the test was administered for participant selection. Table 1 shows the descriptive statistics of this administration with the mean being 34.30 and the standard deviation 6.44, respectively.

TABLE 1

DESCRIPTIVE STATISTICS OF THE PET ADMINISTRATION

\begin{tabular}{|l|l|l|l|l|l|}
\hline & $\mathrm{N}$ & Minimum & Maximum & Mean & Std. Deviation \\
\hline PET Administration & 89 & 22.5 & 50.5 & 34.30 & 6.435 \\
Valid N (listwise) & 89 & & & & \\
\hline
\end{tabular}

Following this administration, the 56 learners whose scores fell between one standard deviation above and below the mean were selected and thence, randomly divided into one control and one experimental group with 28 students in each of the two groups. As discussed earlier, the second and third parts of the PET writing paper were given to the above selected 56 participants in the two groups.

To make sure that the two groups manifested no significant difference at the outset in terms of their writing, i.e. one of the dependent variables of this study, the means of both groups on this writing test had to be statistically compared. Table 2 below displays the descriptive statistics of the scores of the two groups at this stage.

TABLE 2

DESCRIPTIVE STATISTICS OF THE TWO GROUPS ON THE WRITING PRETEST

\begin{tabular}{|l|l|l|l|l|l|l|l|}
\hline & \multirow{2}{*}{} & N & Minimum & Maximum & Mean & Std. Deviation & \multicolumn{2}{l|}{ Skewness } \\
\cline { 6 - 9 } & & & & & & Statistic & Std. Error \\
\hline Exp. & 28 & 5.0 & 18.0 & 12.214 & 4.0812 & -.502 & .441 \\
\hline Cont. & 28 & 4.0 & 18.0 & 12.054 & 3.8833 & -.575 & .441 \\
Valid N (listwise) & 56 & & & & & & \\
\hline
\end{tabular}

Table 2 shows that there was only a negligible difference in the mean scores of the writing test of both groups at the outset (12.21 and 12.05); yet, a statistical comparison was required to make sure that the difference - albeit marginal was not significant. As Table 3 below indicates, with the $F$ value of 0.128 at the significance level of 0.722 being larger 
than 0.05 , the variances between the two groups were not significantly different. Therefore, the results of the $t$-test with the assumption of homogeneity of the variances were reported here. The results $(t=0.151, p=0.881>0.05)$ indicate that there was no significant difference between the mean scores of the two groups on their writing at the outset; consequently, any probable differences at the end of the treatment could be attributed to the effect of the treatment.

TABLE 3

INDEPENDENT SAMPLES T-TEST OF THE MEAN SCORES OF BOTH GROUPS ON THEIR WRITING PRIOR TO THE TREATMENT

\begin{tabular}{|c|c|c|c|c|c|c|c|c|c|}
\hline 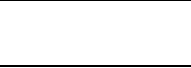 & \multicolumn{2}{|c|}{$\begin{array}{l}\text { Levene's Test for } \\
\text { Equality of Variances }\end{array}$} & \multicolumn{7}{|c|}{$t$-test for Equality of Means } \\
\hline & & & & & & & & $\begin{array}{l}95 \% \mathrm{Cc} \\
\text { the Diff }\end{array}$ & terval of \\
\hline & $F$ & Sig. & $t$ & Df & $\begin{array}{l}\text { Sig. (2- } \\
\text { tailed) }\end{array}$ & $\begin{array}{l}\text { Mean } \\
\text { Difference }\end{array}$ & $\begin{array}{l}\text { Std. Error } \\
\text { Difference }\end{array}$ & Lower & Upper \\
\hline $\begin{array}{l}\text { Equal variances } \\
\text { assumed }\end{array}$ & .128 & .722 & .151 & 54 & .881 & .1607 & 1.0646 & -1.973 & 2.295 \\
\hline $\begin{array}{l}\text { Equal variances } \\
\text { not assumed }\end{array}$ & & & .151 & 53.86 & .881 & .1607 & 1.0646 & -1.973 & 2.295 \\
\hline
\end{tabular}

As discussed earlier, in order to verify the second hypothesis of this study, the ACT test of creativity was run after the writing test and prior to the treatment in order to compare the creativity standing of the learners before and after the treatment. Table 4 below displays the descriptive statistics of this administration in the two groups. As is seen, the mean and standard deviation of the experimental group stood at 72.14 and 12.47 , respectively, while those of the control group were 69.79 and 15.41 , respectively.

TABLE 4

DESCRIPTIVE STATISTICS OF THE TwO GROUPS ON THE CREATIVITY PRETEST

\begin{tabular}{|l|l|l|l|l|l|l|l|}
\hline & $N$ & Minimum & Maximum & Mean & Std. Deviation & Skewness \\
\cline { 6 - 9 } & & & & & & Statistic & Std. Error \\
\hline Exp. & 28 & 46 & 95 & 72.14 & 12.477 & -.322 & .441 \\
\hline Cont. & 28 & 42 & 101 & 69.79 & 15.411 & .155 & .441 \\
Valid N (listwise) & 56 & & & & & & \\
\hline
\end{tabular}

Furthermore, the reliability of the creativity pretest was estimated to be 0.71 using the Cronbach Alpha.

\section{Testing the Hypotheses}

Following the participant selection procedure and the pretests, the treatment was conducted and the writing and creativity posttests were administered in order to check each of the two hypotheses raised in this study.

\section{Testing the First Null Hypothesis}

In order to test the first hypothesis, that is to check any significant difference in the writing of the two groups after the treatment, an independent samples $t$-test was run on the mean scores of the writing posttest.

Firstly, the descriptive statistics of the two groups' scores are presented in Table 5. As is evident, the mean and the standard deviation of the scores of the experimental group were 15.37 and 3.51, respectively. In the control group, however, the above two indices were 12.95 and 3.47 , respectively.

TABLE 5

DESCRIPTIVE STATISTICS OF THE TWO GROUPS ON THE WRITING POSTTEST

\begin{tabular}{|l|l|l|l|l|l|l|l|}
\hline & N & Minimum & Maximum & Mean & Std. Deviation & Skewness \\
\cline { 6 - 9 } & & & & & & Statistic & Std. Error \\
\hline Exp. & 28 & 7.5 & 20.0 & 15.375 & 3.5109 & -.582 & .441 \\
\hline $\begin{array}{l}\text { Cont. } \\
\text { Valid N (listwise) }\end{array}$ & 56 & 6.0 & 19.0 & 12.946 & 3.4677 & -.336 & .441 \\
\hline
\end{tabular}

As Table 6 below indicates, with the $F$ value of 0.012 at the significance level of 0.914 being larger than 0.05 , the variances between the two groups were not significantly different. Therefore, the results of the $t$-test with the assumption of homogeneity of the variances were reported here. The results $(t=2.604, p=0.012<0.05)$ indicate that there was indeed a significant difference between the mean scores of the two groups on their writing following the treatment; consequently, the first null hypothesis of the study stating that using task-based writing has no significant impact on EFL learners' writing performance was rejected with the task-based writing group outperforming the control group significantly in their writing. 
TABLE 6

INDEPENDENT SAMPLES T-TEST OF THE MEAN SCORES OF BOTH GROUPS ON THEIR WRITING POSTTEST

\begin{tabular}{|c|c|c|c|c|c|c|c|c|c|}
\hline & \multicolumn{2}{|c|}{$\begin{array}{l}\text { Levene's Test for } \\
\text { Equality of Variances }\end{array}$} & \multicolumn{7}{|c|}{$t$-test for Equality of Means } \\
\hline & & & & & & & & $\begin{array}{l}95 \% \mathrm{C} \\
\text { the } \mathrm{Di}\end{array}$ & terval of \\
\hline & $F$ & Sig. & $t$ & Df & $\begin{array}{l}\text { Sig. (2- } \\
\text { tailed) }\end{array}$ & $\begin{array}{l}\text { Mean } \\
\text { Difference }\end{array}$ & $\begin{array}{l}\text { Std. Error } \\
\text { Difference }\end{array}$ & Lower & Upper \\
\hline $\begin{array}{l}\text { Equal variances } \\
\text { assumed }\end{array}$ & .012 & .914 & 2.604 & 54 & .012 & 2.4286 & .9326 & .558 & 4.298 \\
\hline $\begin{array}{l}\text { Equal variances } \\
\text { not assumed }\end{array}$ & & & 2.604 & 53.9 & .012 & 2.4286 & .9326 & .558 & 4.298 \\
\hline
\end{tabular}

Following the rejection of the first null hypothesis, the researchers were interested to know how much of the obtained difference could be explained by the variation in the two levels of the independent variable. Accordingly, effect size was also estimated to be 0.33 which according to Cohen $(1988$, p. 22$)$, is considered a moderate effect size. Therefore, the above result could be considered moderately strong enough for the purpose of generalization.

\section{Testing the Second Null Hypothesis}

In order to test the second hypothesis, that is to check any significant difference in the creativity of the two groups after the treatment, an ANCOVA was run on both groups' scores of the creativity pre- an posttests. Firstly, the descriptive statistics of the two groups' scores on these two tests are presented in Table 7.

TABLE 7

DESCRIPTIVE STATISTICS OF THE TwO GROUPS ON THE CREATIVITY PRE- AND POSTTESTS

\begin{tabular}{|c|c|c|c|c|c|c|c|}
\hline & \multirow{2}{*}{$\mathrm{N}$} & \multirow{2}{*}{ Minimum } & \multirow{2}{*}{ Maximum } & \multirow{2}{*}{ Mean } & \multirow{2}{*}{ Std. Deviation } & \multicolumn{2}{|c|}{ Skewness } \\
\hline & & & & & & Statistic & Std. error \\
\hline Pre Exp. & 28 & 46 & 95 & 72.14 & 12.477 & -.322 & .441 \\
\hline Pre Cont. & 28 & 42 & 101 & 69.79 & 15.411 & .155 & .441 \\
\hline Post Cont. & 28 & 43 & 99 & 72.57 & 15.223 & -.147 & .441 \\
\hline Valid (listwise) & 28 & & & & & & \\
\hline
\end{tabular}

The Levene's test for homogeneity of variance was also run as a prerequisite for the ANCOVA and the variances were not significantly different $\left(F_{(1,54)}=1.499, p=0.226>0.05\right)$.

With the above assumptions in place, running an ANVOVA was legitimized. According to Table 8 below, the creativity pretest scores (the covariate in the model) came out to be significant $(F=713.37, p=0.0005<0.05)$ thus demonstrating that prior to the treatment, there was a significant difference between the two groups in terms of creativity. With the eta squared of 0.931 , the pretest covariate accounted for $93 \%$ of the overall variance. Despite the difference prior to the treatment, the effect of the treatment indeed turned out to be statistically significant $(F=0.781, p$ $=0.02<0.05)$. Hence, the second null hypothesis of the study which stated that using task-based writing had no significant impact on EFL learners' creativity was also rejected with those receiving the treatment outperforming significantly those in the control group.

TABLE 8

TESTS OF BETWEEN-SUBJECTS EFFECTS

\begin{tabular}{|l|l|l|l|l|l|l|l|l|}
\hline Source & $\begin{array}{l}\text { Type III Sum of } \\
\text { Squares }\end{array}$ & df & Mean Square & $F$ & Sig. & $\begin{array}{l}\text { Partial Eta } \\
\text { Squared }\end{array}$ & $\begin{array}{l}\text { Noncent. } \\
\text { Parameter }\end{array}$ & $\begin{array}{l}\text { Observed } \\
\text { Power }\end{array}$ \\
\hline Corrected Model & $10624.479^{\mathrm{a}}$ & 2 & 5312.240 & 361.72 & .000 & .932 & 723.441 & 1.000 \\
\hline Intercept & 27.814 & 1 & 27.814 & 1.894 & .017 & .035 & 1.894 & .272 \\
\hline Creativity Pretest & 10476.604 & 1 & 10476.604 & 713.37 & .000 & .931 & 713.372 & 1.000 \\
\hline Group* & 11.469 & 1 & 11.469 & .781 & .02 & .165 & .781 & .140 \\
\hline Error & 778.360 & 53 & 14.686 & & & & & \\
\hline Total & 319689.00 & 56 & & & & & & \\
\hline Corrected Total & 11402.839 & 55 & & & & & & \\
\hline
\end{tabular}

According to Table 8, the partial eta squared value for the group factor was 0.165 which according to Cohen (1988) is a large effect size meaning that $16 \%$ of the variance was explained in this study. Furthermore, there was a strong relationship between the pre- and post-intervention scores on the creativity test as indicated by the R squared of 0.932 .

\section{DISCUSSION}

There have been various studies conducted in recent years pointing to the positive impact of TBLT on the writing ability of learners (Latchem, Latchem, \& Jung, 2010; Pourdana, Karimi Behbahani, \& Safdari, 2011). Latchem et al. (2010) also concluded that the task-based approach while using multimedia enhanced learners' creativity. The findings of this research of course corroborated the findings of such studies.

As stated by some researchers (e.g. Malone, 2003; Soliman, 2005), there exist certain barriers to creativity which inhibit creative ideas to come into existence. In this study, peer feedback which - according to Chandler (2003) - 
minimizes those barriers through the reinforcement of cooperative learning was encouraged. Peer feedback was thus a crucial element in the task-based writing group bearing an impact on the environmental barriers to creativity and culminating in more active involvement of the learners in the learning process.

At the same time, peer feedback provided the learners with a less threatening environment free of the tension of being evaluated and scored by the teacher. This granted them the chance of overcoming their psychological barriers to creativity which are classified by Soliman (2005) as the most influential factors that block creativity.

Throughout this study, learners also benefited from reading models, picture prompts, audio CDs, and discussions over the writing topics before and after the writing; these tasks provided them with an adequate amount of input which helped them in practice to gain the capacity required to express their ideas more fluently and accurately in writing and overcome their expressive blocks to creativity.

As noted by Carless (2009), TBLT brings about more successful language learning on the part of the learners by actively involving them in doing tasks which indeed result in their higher levels of motivation. Throughout the course of this study, the researchers clearly observed that employing different tasks, following task cycles, making use of cooperative learning, and different kinds of feedback provide the learners in the experimental group with an environment in which they were really interested in what they were writing. According to Grainger et al. (2005), such an environment is characteristically conducive towards the creative writing context which has the potential of institutionalizing liveliness, communication, and energy in class and can, together with certain other factors, result in the enhancement of both the creativity and writing capacity of learners.

\section{CONCLUSION}

When it comes to writing, teachers may encounter certain problems on the part of the learners such as lack of participation and motivation. Quite a number of students do not know how to initiate their writing since they have not been provided with enough input to help them generate new ideas and enough motives to actively take part in the learning process. As is clear from the findings of this study, it is very important for writing teachers to utilize different types of tasks, provide learners with adequate amount of input, actively involve them in the class procedures, and encourage them to be more creative in their writing and write their first draft freely without any concern for formal linguistic features.

Alongside teachers, syllabus designers and material developers may want to consider tasks as the building blocks for classroom teaching and for designing instructional activities. Some books can be designed with their focus specifically directed toward different types of writing tasks with their teachers' guide which help teachers in the application of those books. In this way, teachers are provided with a rich source from which they can pick out some tasks according to the interests of their learners and the immediate context of their teaching. It is also important to pay more attention to learners' creativity in the educational system and design course books with more emphasis on promoting this attribute in learners.

Following the findings of this research, a number of recommendations can be discussed for further investigation among which, the researchers wish to emphasize the following:

1. The same research can be run with a focus on other individual variables like motivation, introversion/extroversion, and learning styles.

2. The focus of this study was on the overall writing performance of learners, while it is possible to see the effect of using task-based writing on a specific writing mode like narrative writing and its potential impact on creativity.

3. It is possible to replicate this study with other age groups such as children or adults and see whether the result would perhaps be different.

\section{REFERENCES}

[1] Agrawal, K, P. (1992). Development of creativity in Indian schools: Some Related Issues. New Delhi: Concept Publishing Company.

[2] Auzmendi, E., Villa, A., \& Abedi, J. (1996). Reliability and validity of a newly constructed multiple-choice creativity instrument. Creativity Research Journal, 9, 89-96.

[3] Bernholz, J. F., Cappleman, H., \& Sumner, P. H. (1992). Success in reading and writing. Glenview, IL: Scott Foresman.

[4] Carless, D. (2009). Revisiting the TBLT versus P-P-P Debate: Voices from Hong Kong. Asian Journal of English Language Teaching, 19, 49-66.

[5] Carter, R. (2004). Language and creativity: The art of common talk. New York: Routledge.

[6] Chaudron, C. (1985). The role of simplified input in classroom language. In G. Kasper (Ed.), Learning, teaching and communication in the foreign language classroom (pp. 99-110). Arhus: Arhus University Press.

[7] Chandler, J. (2003). The efficacy of various kinds of error feedback for improvement in the accuracy and fluency of L2 student writing. Journal of Second Language Writing, 12, 267-296.

[8] Cohen, J. (1988). Statistical power analysis for the behavioral sciences (2nd ed.) Hillsdale, NJ: Lawrence Erlbaum.

[9] Cropley, A. J. (2001). Creativity in education and learning: A guide for teachers and educators. London: Kogan Page.

[10] Ellis, R. (1991). Understanding second language acquisition. Oxford: Oxford University Press.

[11] Ellis, R. (2003). Task-based language learning and teaching. Oxford: Oxford University Press. 
[12] Errey, L., \& Schollaert, R. (2003). Whose learning is it anyway? Developing learner autonomy through task-based language learning. Antwerp: Garant.

[13] Grainger, T., Goouch, K., \& Lambirth, A. (2005). Creativity and writing: Developing voice and verve in the classroom. New York: Routledge.

[14] Kawachi, P. (2003). Initiating intrinsic motivation in online education: Review of the current state of the art. Interactive Learning Environment, 11, 59-81.

[15] Kellogg, R. T. (1994). The psychology of writing. Oxford: Oxford University Press.

[16] Kim, Y., \& Kim, J. (2005). Teaching Korean university writing class: balancing the process and the genre approach. Asian EFL Journal, 7(2), 1-15.

[17] Klapper, J. (2003). Taking Communication to task? A critical review of recent trends in language teaching. Language Learning Journal, 27, 33-42.

[18] Latchem, C., Latchem, C. R., \& Jung, I. (2010). Distance and blended learning in Asia. New York: Taylor \& Francis.

[19] Lee, C, F, K. (2004). Language output communication strategies and communicative tasks: In the Chinese context. Lanham, MA: University Press of America.

[20] Lubart, T. I. (1999). Componential models. In M. A. Runco, \& S. R. Pritzker (Ed.), Encyclopedia of creativity: Volume 1 (pp.295-300). San Diego, CA: Academic Press.

[21] Lubart, T. \& Guignard, J. H. (2004). The generality-specificity of creativity: A multivariate approach. In R. J. Sternberg, E. L. Grigorenko, \& J. L. Singer (Eds.), Creativity: From potential to realization (pp. 43-56). Washington, DC: American Psychological Association.

[22] Malone, S. A. (2003). Learning about learning: An A-Z of training and development tools and techniques. London: CIPD.

[23] McCarthy, M., McCarten, J., \& Sandiford, H. (2006). Touchstone. Cambridge: Cambridge University Press.

[24] McDonough, S. H. (1995). Strategy and skill in learning a foreign language. London: Edward Arnold.

[25] Mishan, F. (2005). Designing authenticity into language learning materials. Bristol, UK: Intellect Books.

[26] Neira, D. A. (2008). Creative writing. India: Dorling Kindersley.

[27] Oxford, R. L. (1997).Cooperative learning, collaborative learning, and interaction: Three communicative strands in the language classroom. The Modern Language Journal, 81(4), 443-456.

[28] Parameswaram, G. (2007). Inclusive writing in a psychology class. Journal of Instructional Psychology, 34 (3), $172-176$.

[29] Pourdana, N., Karimi Behbahani, M., \& Safdari, M. (2011). The Impact of Task Types on Aspects of Iranian EFL Learners' Writing Performance: Accuracy, Fluency, and Complexity. IPEDR, 20, 261-265.

[30] Rao, D. B., \& Prasad, S. S. (2009). Creative thinking of school students. New Delhi: Discovery Publishing House.

[31] Richards, J. C. (1990). The language teaching matrix. Cambridge: Cambridge University Press.

[32] Richards, J. D., \& Renandya, W. A. (2002). Methodology in language teaching: An anthology of current practice. Cambridge: Cambridge University Press.

[33] Richards, J. C., \& Rodgers, T. S. (2001). Approaches and methods in language teaching. Cambridge: Cambridge University Press.

[34] Ryan, R. M., \& Deci. E. M. (2000). Self-determination theory and the facilitation of intrinsic motivation, social development and well-being. American Psychologist, 55(1), 68-78.

[35] Sarsani, M. R. (2006). Creativity in schools. New Delhi: Sarup \& Sons.

[36] Sarsani, M. R. (2005). Creativity: Definition and approaches. In M. R. Sarsani (Ed.). Creativity in education (pp. 1-7). New Delhi: Sarup \& Sons.

[37] Saslow, J., \& Ascher, A. (2006). Top notch. New Jersey: Pearson.

[38] Silva, T. (1993). Toward an understanding of the distinct nature of L2 writing: The ESL research and its implications. In T. Silva \& P. K. Matsuda (Eds.), Landmark essays: On ESL writing (pp. 191-208). Mahwah, NJ: Lawrence Erlbaum Associates.

[39] Soliman, S. A. H. (2005). Systems and creative thinking. Egypt: Center of Advancement of Postgraduate Studies and Research in Engineering Science.

[40] Sternberg, R. J. (2009). Domain-generality versus domain-specificity of creativity. In P. Meusburger, J. Funke, \& E. Wunder (Ed.), Milieus of Creativity: An interdisciplinary approach to spatiality of creativity (pp. 25-38). Dordrecht: Springer.

[41] Szymanski, M. H. (2003). Producing text through talk: Question-answering activity in classroom peer groups. Linguistics and Education, 13(4), 533-563.

[42] Tilfarlioglu, F. Y., \& Basaran, S. (2007). Enhancing reading comprehension through task-based writing activities: An experimental study. The Reading Matrix, 7(3), 134-152.

[43] Van den Bergh, H., Rijlaarsdam, G., \& Sanders, T. (2005). Writing processes in L1 and in a foreign language: a first exploration. In L. Allal \& J. Dolz (Eds.), Proceedings writing 2004. Geneva: Adcom Productions.

[44] Willis, D., \& Willis, J. (2007). Doing task-based teaching. Oxford: Oxford University Press.

Hamid Marashi is Assistant Professor of Applied Linguistics, Islamic Azad University at Central Tehran and Executive Manager of the Journal of English Language Studies (JELS). He currently teaches the graduate courses of seminar in TEFL issues, discourse analysis, and teaching language skills and his main areas of research interest include cooperative learning, collaborative teaching, critical thinking, and TBLT. He has published in national and international academic journals and presented in international conferences.

Lida Dadari holds an MA in TEFL from Islamic Azad University at Central Tehran and is an English teacher at a number of language schools in Tehran. Her main area of research interest is using innovative techniques in ELT. 